\title{
WILLIAM MORRIS, A TRANSCULTURAL ARTIST AND MAN OF LETTERS
}

\author{
ISABELLE GADOIN \\ UMR 7172 Thalim (CNRS), Université de Poitiers, Laboratoire FoReLLIS B1, \\ EA 3816
}

\begin{abstract}
William Morris is extremely famous for his career as a designer and one of the founders of the whole movement of the Arts and Crafts in Late Victorian England. But the other side of his career, as a man of letters, is far less abundantly documented. While his Socialist utopia News from Nowhere (1890) is still read and commented upon today, far less attention has been given to his early poems, as well as his late romances written in a mock- mediaeval style which was to inspire the whole twentieth-century movement of "Fantasy" literature.The article focuses on Morris's partly neglected love of letters, both in the sense of literature as a whole, and of individual letters. Morris loved the letter as a writer, but also as a visual artist: from an early stage of his career, he practiced calligraphy as leisure, before turning to book-printing as a professional activity in the last years of his life. This love of letters is studied on the basis of a particular case-study: his production of a calligraphic and illustrated version of the mediaeval Persian poems of Omar Khayyam, the Rubbayiat, in their English translation by Edward FitzGerald (1859). Aside from his passion for letters, in both their graphic and poetic dimension, Morris's work on the Rubbayiat shows how deeply intercultural and intermedial his inspiration was. He recreated for the English readers of the Persian poet a visual world which borrowed from his other creations in the field of textiles, carpets, wall-papers, etc., and brought together East and West in a completely hybrid visual creation. It is those eminently cross-cultural and trans-disciplinary sources of inspiration that the article unravels.
\end{abstract}

Keywords: Arthurian legend, calligraphy, Gothic Revival, history of collections, illuminated books, manuscripts, Rubái'yát, translation, typography. 
William Morris (1834-1896) is world-famous as the High Victorian designer who entirely reformed and regenerated taste in the last quarter of the nineteenth century, launching the movement of the Arts and Crafts, which was to influence the wider European movement of Art Nouveau after the turn of the twentieth century. With his firm Morris, Marshall, Faulkner and Co, Decorators, founded in April 1861, Morris set about producing furniture of all kinds, woodwork, tooled leather, general decoration, silverwork and jewellery, and soon after this, tapestry, carpets, embroideries, ceramic tiles, wallpapers, textiles and chintzes... In the collective imaginary, he is the designer who made new, essentially vegetal and floral, motifs the quintessence of "British" home decoration. Yet there is another facet to Morris, which has been so overshadowed by his brilliant decorative productions as to appear almost secondary in his official biography, that is, his work as a man of letters, in all senses of the word; a poet, a translator, an essayist, an indefatigable political pamphleteer, a prolix letter-writer (his Collected Letters were published in five volumes by Norman Kelvin from 1984 to 1996) and, in the last decade of his career, a novelist, as well as a printer and a publisher, with the creation of the Kelmscott Press in 1891. To this end he eagerly researched and rediscovered mediaeval printing techniques, in order to produce beautifully illustrated books.

Of all these scriptorial activities, this paper focuses on one in particular, which most closely expresses Morris's passion for letters, that is, handwriting, calligraphy, and the ancient manuscript art-one of the aspects perhaps less researched in the whole of his productions. There were three distinct phases in his progressive involvement with manuscript art: as a boy, he had seen manuscripts at Canterbury cathedral, and during his years of study at Oxford "from 1853 to 1855, he was a consistent visitor to the Bodleian, as can be seen from the Visitors' Book (though which were his favourite manuscripts remains a matter of mere guesswork)" and in later life he was to become so familiar with the manuscripts in the British Museum that (as his daughter May remarked) he liked to consider them his" (Nash 296-97). Then in the years 1870 to 1875, he entertained himself writing and decorating his own manuscripts. He worked on 21 of them (Nash 296), but few ever came to completion, for the practice was pure leisure, and was never part of his commercial activities. Yet it enabled him to fully acquire the aesthetic and practical mastery of mediaeval lettersunderstood here in their graphic dimension. His later production of printed books with the Kelmscott Press therefore resulted from a long, almost uninterrupted training as a lover and a practitioner of calligraphy.

Finally, in the last decade of his life, at the same time as he launched his own private Press, he also started collecting mediaeval manuscripts or early printed books, with the passion which never left him, spending up to several hundred pounds at a time on a single volume. Thus he ended his career as a book-lover surrounded with a whole circulation of books, buying ancient 
treasures of bibliophily, while at the same time selling his own modern printed recreations in mediaeval fashion. Bill Peterson and Sylvia Holton-Peterson's ongoing project of online cataloguing of his personal library (https://williammorrislibrary.wordpress.com/) already lists some 2,400 entriesmaybe not a considerable figure for a private library, but the appreciation somewhat changes when one realizes that Morris owned books going as far back as the eleventh and twelfth centuries, including illuminated bibles, missals, psalters and books of hours, breviaries, antiphonaria, bestiaries, herbals, collections of tales, early scientific treatises dealing with medicine, cosmology, geometry, architecture, history or law. Just as important, if not more, was a collection of some 50 incunabula-the first printed books of the Gutenberg revolution. A good notion of the eminent quality of this library is to be derived from the fact that many of Morris's books are now in the Los Angeles Getty Museum or the New York John Pierpont Morgan Library, two of the most distinguished American collections. Although Morris wrote that he owned 82 ancient manuscripts around 1895, his collection was in fact estimated to be closer to 112 volumes (Kelvin, vol. 4, 385). After Morris's death many of these were bought by Mr Richard Bennett (Kelvin 385) for the sum of £18,000-the equivalent of some two million pounds today, according to online currency converters. It is Bennett who re-auctioned part of this treasure through Sotheby's in December 1898, and sold the remainder to the unsurpassed collector J.P. Morgan.

Interestingly, one of the modern books he owned was the three-volume sum by George Stephens on The Old-Northern Runic Monuments of Scandinavia and England, now first collected and deciphered, printed in London by J.R. Smith and in Copenhagen by Michaelsen and Tillge, from 1866 to 1884, and including "many hundreds of facsimiles and illustrations." ${ }^{1}$ This confirms the fact that Morris, as a creator, envisioned words and letters-and more largely, all signifying traces, like old runes-primarily as graphic signs, or designs; and he never stopped collecting and using these designs as sources of inspiration. Even though Morris's bibliophile activities climaxed in the 1890sin the last ten years of his life-they were in fact the expression, and the culmination, of a profound love of words, both oral and written, old and new, which had started in his youth.

This article proposes to show that Morris's passion for words was really the red thread running throughout his life, and is probably to be understood in the same way as his involvement with the decorative arts: the two derived from the same deeply sensuous and even physical type of apprehension and concern for beauty, but also from the same cult of hand-work. In the affectionate

\footnotetext{
${ }^{1}$ https://williammorrislibrary.wordpress.com/2014/10/03/\%C2\%B6-stephens-oldnorthern-runic-monuments/ (accessed 26/05/2019).
} 
caricatures which Burne-Jones and Max Beerbohm drew of him, Morris is either presented in worker's clothes, intently curled up upon his handicraft, or waving an authoritative hand, while reading or declaiming his poems. The hand for him was the supreme tool, and he made this one of the tenets of his anti-industrial creed, which was to guide the whole of the creations of the Arts and Crafts. His approach of language, and of individual letters, was a deeply embodied and physical one. He loved words and books for their visual and even material quality: their shape, graphic aspect, their constructive capacities on the page, and even their figurative potential. And the point of this article is that the verbal and the visual played an equal role in his productions; they were really the two sides of the same coin, or of the same sheet to apply the appropriate metaphor; and this thesis calls for a re-appraisal of Morris's written works as not only complementary but truly consubstantial to his so-called "decorative" productions.

I will show this by first focusing on Morris's discovery of mediaeval texts in his youth, insisting on the fact that he valued them not only for their content-mostly the romance of Arthurian legends-but also for their material aspect as books. I will then focus upon one particular case-study: the manuscript version of the quatrains by the Persian poet Omar Khayyám, designed as a present for Burne-Jones's wife Georgiana, almost at mid-point in his career, in 1872. I will conclude with some considerations about Morris's deeply transcultural inspiration, and the fact that his manuscript art, precisely because it is not only verbal but also strongly visual, has a strong universal flavour.

\section{Discovering Mediaeval Texts}

From his early years, and notably those of his studies at Oxford, Morris showed himself to be deeply influenced by the power of words. At Oxford, he met Edward Jones, who was later to become Burne-Jones (when adding his deceased mother's name to his father's), and to be Morris's lifelong friend and work partner. After briefly thinking of entering the clergy, and then trying his hand at architecture, Morris finally turned towards art, on the advice and influence of the charismatic Dante Gabriel Rossetti, himself both a painter and poet, and one of the founders of the Pre-Raphaelite Brotherhood in 1848. But one should not mistake this career choice as precluding any literary pursuit: on receiving the plump sum of 900 pounds on his coming-of-age, Morris decided to invest a large part of it into the creation of the Oxford and Cambridge Magazine inspired by the first few issues of the Pre-Raphaelite magazine The $\mathrm{Germ}^{2}$ and defined as "a collection of 'mainly tales, poetry, friendly critique and social articles" (McCarthy 1994, 98). This was a very short-lived experience, running for twelve

\footnotetext{
${ }^{2}$ See http://www.rossettiarchive.org/docs/ap4.o93.raw.html (accessed 10/05/2019).
} 
months only, from January to December 1856, but Morris was nevertheless able to publish in the magazine at least eight prose tales, five poems, an article on the Gothic cathedral of Amiens (visited with Burne-Jones in the summer of 1855), a study of the engravings of the German history painter Alfred Rethel, and a review of Robert Browning's poem Men and Women (McCarthy 1994, 100)—a list which gives a good idea of the variety of subjects dealt with in the magazine.

These were the times of Gothic Revival, spurred by the writings of Thomas Carlyle and John Ruskin, whose Stones of Venice served as Morris and Burne-Jones's favourite guide-book on their 1854-1855 travels on the Continent: here too, aesthetic appreciation was developed through the filter of books. Encouraged by Carlyle and Ruskin's fiery denunciations of the evils of industrial society and standardized work, the young artists of this generation fantasized the Middle Ages as the exact counterpoint of capitalist society, and viewed mediaeval England as an ideal example of egalitarianism and paternalism. Morris's biographer Fiona McCarthy defined the Oxford and Cambridge Magazine as an instrument in the struggle against the ravages of modernity: "it was part of the Brotherhood's crusade against the age" (McCarthy 1994, 98).

If one is to look for a foundational text in Morris's career, it is to mediaeval times therefore that one has to turn. In the exalted summer of 1855 Morris and Burne-Jones discovered with a thrill the episode of the death of King Arthur as told by the late mediaeval author Sir Thomas Malory (c.1405-71) in Morte Darthur, a text printed by William Caxton in 1485, but re-edited by Robert Southey in 1817, shortly before its rediscovery by the Pre-Raphaelites. Barry Gaines has written in detail about the discovery of the text by the two men, in terms suggesting something of an almost religious veneration:

the copy of Southey's edition [...] attracted young Edward Burne-Jones in Cornish's bookshop around 1855. Unable to purchase the volumes, BurneJones read it in the shop "day after day, and bought cheap books to pacify the owner." His friend William Morris, however, bought the book 'as soon as he set eyes on it and had it bound in white vellum, and so great did their love and veneration for this book become that he and Burne-Jones were almost too shy to speak of it.' Burne-Jones's widow recalls 'some times I think that the book never can have been loved as it was by those two men. With Edward it became literally a part of himself.' (Gaines 16)

From the early date of 1855, when Morris was only 21, he owned a modern copy of the mediaeval text, which he truly worshipped, notwithstanding the fifteenth-century spelling which Southey had abided by and which makes access to the text somewhat demanding today. The fact that from the start Morris had the book re-bound shows his instinctive concern for the book as object and not only for the story told. This early purchase means that Morris was familiar with 
the title-page engraving as well as the gothic letters used in chapter heads, and this was an important first step in his training as a manuscript- and book-lover. When he got hold of a better copy of the volume in 1888, he presented the first one, with a dedication, to his colleague and friend Emery Walker, whose widow, in turn, donated it to the Bodleian library, with a note explaining the truly foundational value of that discovery: "This is the copy that William Morris bought in Birmingham, Burne-Jones having told him that he had been reading it in the Bookseller's shop-all the Morris set read it from this copy.” ${ }^{33}$ Indeed, as the two men read aloud from the text to their London friends, the passion soon became infectious; Ford Maddox Brown, Rossetti and Swinburne caught the virus, and Arthurian themes started blooming everywhere in poetry and painting. Dante Gabriel Rossetti, Fiona McCarthy explains, being "older and brasher, pronounced that the Morte d'Arthur and the Bible were the greatest books in the world" (McCarthy 1994, 97).

Such was the strength of that inspiration that Morris himself produced his own versified retelling of Arthurian romance in 1858, under the title The Defence of Guenevere and Other Poems-a volume dedicated to Rossetti. Interestingly, Tennyson's Idylls of the King, first published from 1859, and expanded all along the next two decades, only followed suit. That means that even though Rossetti, Tennyson and Swinburne conquered fame as poets, Morris had in fact led the way in turning Arthurian themes into verse, and Peter Falkner appositely insisted upon this ground-breaking role: "The Defence of Guenevere was the first book of Pre-Raphaelite poetry to be published-neither Rossetti nor Swinburne had yet done so" (Faulkner 45).

Simultaneously, in 1858, Morris painted an oil canvas-the only one he is known to have produced in his entire life, and apparently with great difficulty, as testified by the many repaints. Because the canvas came at about the same time as his Guenevere poem, it was long thought to be a portrait of Arthur's adulterous wife; but contemporary analysts rather incline to see in it a picture of La Belle Iseut, ${ }^{4}$ a theme also drawn from Malory. Iseut is represented waiting for Tristan, in a melancholy pose before her mirror, her little dog curled up in her sheets, as if longingly waiting for his master too. The model for the figure was Jane Burden, whom Morris was to marry the following year, in 1859. The whole canvas already testifies to Morris's passion for textiles, as the room looks like an orchestrated display of varied types of rich fabrics: the background tapestry, bed curtains, sheets and cover, the carpet and the mantle on the side

\footnotetext{
${ }^{3}$ William Morris Library, Online Catalogue, https://williammorrislibrary.wordpress.com/2017/07/25/\%C2\%B6-malory-byrth-lyfand-actes-of-kyng-arthur-1817/ (accessed 09/05/2019).

${ }^{4}$ See https://www.tate.org.uk/art/artworks/morris-la-belle-iseult-n04999 (accessed 26/05/2019).
} 
table, to end with Iseut's elegant printed dress, all appear as an exercise in representing sensuous textiles.

But what catches our eye in this context is the puzzle offered by the small embedded still life on the side table: indeed, while the mirror, the hairbrush, and the fruit-bowl-with its oranges visually recalling the pomegranates on the table-cloth—all suggest sensuousness and the forbidden fruits of Eden, the open missal on the contrary offers the only reminder of spiritual life here. Or is it possible to think that this book was actually not a missal, a Bible, a breviary or a book of hours, but perhaps the mise en abyme of Malory's text-and therefore authorship-inside the scene which illustrated one of the episodes he had narrated? The uncertainty is also cultivated by the ambiguous treatment of the book, both visual and verbal: it appears side by side with the mirror, clearly associated with sight; but Morris took pains to render the look of the written lines, while the illuminated initial, bearing resemblance with those in books collected or printed by Morris, stands half-way between the visible and the legible. In a late photograph of Morris's library a book stands proudly open on a lectern in the foreground of the picture, obviously to be seen rather than read. ${ }^{5}$ On the open page can be discerned an illuminated letter somewhat comparable to that of his "Iseut" painting. Finally, Iseut's manuscript also calls on to the tactile sense, with its thick dog-eared pages evoking vellum, and thus partaking of the global suggestion of touch in this luxurious representation of textiles.

\section{The Pre-Raphaelite Discovery of Omar Kahhaym's Rubai'yat}

1859 was also the year when Morris and his Pre-Raphaelite friends discovered a text destined to an incredible posterity. This was the "rubái'yát", or "quatrains" of Omar Khayyám (born 1050-60, died 1123), a mysterious mediaeval Persian mathematician, astronomer and more marginally a poet, who had just been translated into English by the man of letters and polymath Edward FitzGerald (1809-1883) (Goldfarb; see also Djavadi; Gadoin 2000). The story of this discovery was told countless times and is very well-known as an episode of Victorian literary history, so I will just go very briefly through the major lines leading us back to Morris's work, because I am more interested in the materiality of the book than in the vicissitudes of its translation. It is the Orientalist Edward Byles Cowell (1826-1903), originally a disciple of William Jones, but largely self-taught in Persian (see Thomas), who discovered a copy of the quatrains in 1856 at the Bodleian Library, in the Ouseley collection-from the name of the diplomat who had led a pioneer diplomatic mission to Persia in

\footnotetext{
${ }^{5}$ See the engraving of the photo on the homepage of William Morris Library website: https://williammorrislibrary.wordpress.com/ (accessed 26/05/2019).
} 
1810, on which occasion he gathered an impressive collection of old Persian manuscripts. The manuscript was not illustrated, apart from a simple decorated band at the top of the first page, as well as the very traditional colophon, indicating the end of the work (see Heron-Allen).

FitzGerald undertook a translation of the poems with Cowell's help. In June 1856, Cowell left for India, where he took up a position as a Professor of History at the University of Calcutta. There, in the library of the Asiatic Society, he found two more copies of the Rubái'yát, one of which he sent to FitzGerald in March 1857. FitzGerald went on with his translation, taking considerable liberties with the text, which he turned into a song of praise to hedonism, completely disregarding the initial mystical (and probably sufi?) inclinations of the quatrains. He sent a first version of 35 quatrains to Fraser's Magazine, which failed to publish them, and thus he retrieved them and added some 40 more quatrains, coming up to a total of 75 quatrains, of which he had 250 copies privately printed. However, these did not sell at all, and they languished on bookstalls until relegated to the "penny box", to be sold away for one penny... Their fate started changing in 1861, when Rossetti and Swinburne chanced upon them, fell in love with the light carpe diem philosophy which they read between the lines, and launched the craze among their Pre-Raphaelite friends. Thus started the incredible saga of the Rubái'yát, soon to become a Victorian bestseller: in 1868, FitzGerald published a second edition, in which the number of poems added up to 110 , then other editions in 1872, 1879, and posthumously 1889, all three presenting a text brought back to 101 poems.

Morris was part of the small circle of Pre-Raphaelite artists who rediscovered or, better said, reinvented Khayyám's Quatrains, and he could hardly fail to join in the craze... But typically, this meant for him giving physical shape to the text as a sensuous and beautiful object-as if visual appearance mattered more than questions of content and interpretation. He had first tried his hand at calligraphy in 1856, and Rossetti deemed him to be "unrivalled among moderns in all illumination and work of that kind" (Rossetti qtd by Nash 297). He worked on the 1859 version, and retained the original 75 poems in the order chosen by FitzGerald — who had already deeply transformed the nature of the original text: whereas Khayyám's quatrains were certainly written as occasional epigrams, not meant to be read together, FitzGerald reorganized them by fusing them all into a long narrative cycle, starting at morning and ending at night, and explicitly calling for the enjoyment of life's sensual pleasures - symbolized in the Persian text by love and wine-in view of the brevity of human existence. Although Morris hardly seems to engage with the content and meaning of the text itself, and although his creation offers little insight, if at all, into the spirit of Persian poetry, his imagination, as that of his poet and painter friends, was certainly fired by Khayyám's sensuous metaphors, evoking images of lush gardens, fertile Springs and cosy taverns where joyful 
youths with "incarnadine" cheeks (quatrain 6) drink the Vine's "ancient ruby yield” (quatrain 5).

However, this assertion that Morris largely disregarded the real content of the text to deal with it as purely sensuous matter might need mitigating, taking his aim into consideration: the volume was meant to be a present for Georgiana Burne-Jones, his friend's wife. At that point both Morris and Georgiana had gone through rather troubled times in their respective marital lives, and these difficulties brought them closer together in what was to be an affectionate but muted and respectful life-long friendship. On the one side Rossetti had been passionately in love with Jane Burden, Morris's wife, whom he portrayed almost obsessively from the early 1860s, ${ }^{6}$ turning her into the archetype of Pre-Raphaelite beauty - with Morris unable to take it upon himself to violently break the relationship (see McCarthy 1994, 231-277). On the other side Burne-Jones had embarked into a tempestuous affair with Maria Zambaco, a Greek beauty also evolving in Pre-Raphaelite circles, and who had been modelling for him; ${ }^{7}$ the affair came to a head in January 1869 , when she threatened to commit suicide by drowning after drinking laudanum, and he at last broke up with her (McCarthy 2011, 199-211). In that emotionally tense context, Morris's gift of the Rubái'yát could be interpreted as an implicit encouragement to Georgiana on the part of another friendly soul. Melancholy verses like "The thoughtful soul to solitude retires" (quatrain 4), or "The worldly hope we set their hearts upon / Turns to ashes" (quatrain 13), or even terser, flatter Epicurean maxims like "time is slipping underneath our feet" (quatrain 37) may have convinced Georgiana that another heart was communing with hers in silent suffering.

In 1870, shortly before the Rubái'yát, Morris had already offered Georgiana a Book of Verse $e^{8}$ (see Nash 303, N.5) containing poems of his, as well as two translations from Icelandic sagas-a venture he had undertaken in 1868 with the collaboration of the Icelander Eiríkur Magnússon (1833-1913). He was to visit Iceland twice, first in July 1871, then again two years laterapart from his newly-discovered interest in that country, the impulse was partly to flee from his domestic troubles. The simultaneity of these two passions, calligraphy and translation, shows that Morris enjoyed playing with the meanings of words as signifieds in different linguistic contexts, but also with their material dimension as signifiers, both oral, in the churning out of verses, and written, in their calligraphic transposition on the page. He was to retain this interest for translation throughout his life: in 1875, shortly after his work on

\footnotetext{
${ }^{6}$ See the work on the site of Tate Britain: https://www.tate.org.uk/art/artworks/rossettiproserpine-n05064 (accessed 12/04/2020).

${ }^{7}$ See https://en.wikipedia.org/wiki/Maria_Zambaco\#/media/File:Edward_BurneJones_Maria_Zambaco_1870.jpg (accessed 12/04/2020).

${ }^{8}$ See https://www.vam.ac.uk/articles/william-morris-text (accessed 12/04/2020).
} 
Khayyám, he translated the Aeneid, and went on in 1886 with a translation of the Odyssey, which came out in April 1887. It took him a full year, from February to December 1886, to go through the twelve books of the Odyssey (see Kelvin, vol. 2-b, 525-615) - no mean feat in comparison with the 75 quatrains, amounting to 300 lines, translated by FitzGerald. His letters make it clear that Morris saw translation as leisure. Indeed he wrote to his daughter: "I amused myself partly with Homer [110 lines]", while we know from the same letter that he was also reading Russian Epic songs (Kelvin 578, Letter to Jenny Morris, dated Sunday Sept. 26, 1886). His manuscripts are thus to be understood as another way of keeping both hand and mind going leisurely, and they spring from the same voracious interest in the discovery of world-literatures.

\section{Morris’s “Persian” Manuscript}

There are four calligraphic versions of the Rubái'yát, only one of which was fully completed (Nash 305). One of these was produced by Morris in 1872, shortly after his Book of Verse. Like the latter, this was a collaborative work, with Morris writing the text, and Edward Burne-Jones painting the elongated female figures so characteristic of his own art, and of Pre-Raphaelitism as a whole. Burne-Jones's assistant Charles Fairfax Murray was also in charge of some of the decoration (cf. fig. 1). Early versions were not so profusely decorated as the completed one, but they adopted a device strongly reminiscent of William Blake's illuminated books-though these were not calligraphic work, but were printed with the technique of etching. As in Blake's work, branches and tendrils of foliage in the right hand-side margin flood the page but also serve to separate the various stanzas, and seem to mix in with the drawing of the letters-notably the capitals in the title. Morris on the whole keeps the same architecture of the page, with human figures reduced to a minimum and the whole visual animation relying on the vegetal scrolls. 


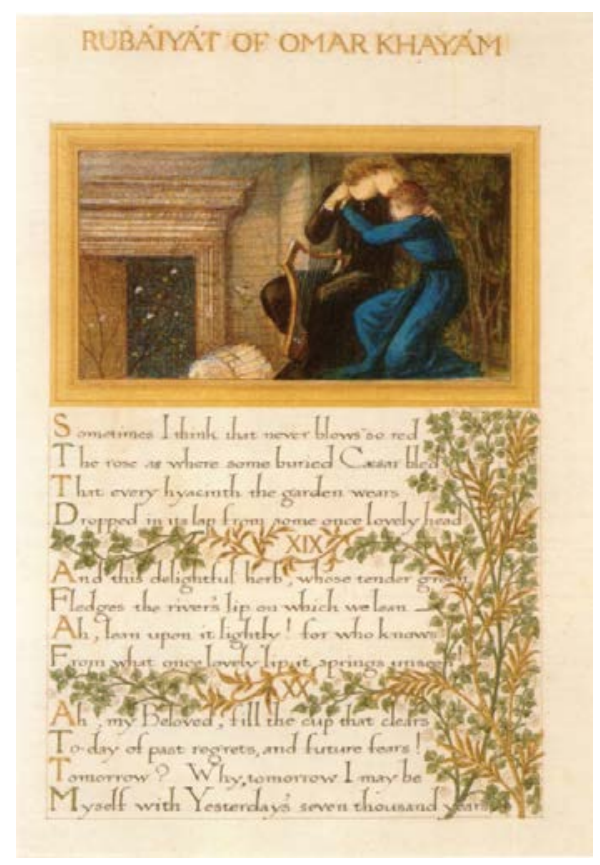

Fig. 1: Rubaiyat of Omar Khayyam, watercolor, bodycolor and gold leaf (1870). Calligraphy and ornamentation by William Morris, illustrations by Edward Burne-Jones. Wikimedia Commons ${ }^{9}$

However, it is Morris's only completed version of illuminated Rubái'yát, now at the British Museum, and also copied in 1872 ( ${ }^{\circ}$ Add MS 37832), which I want to focus on more narrowly now. Again, the volume was be a present for Georgiana, as testified by the capital $G$ repeated in the upper margins, and one may wonder whether the dedication to Georgiana did not also hide within the text itself, with a stanza that sounds as an implicit recall of Morris's previous gift to her: "a flask of wine, a book of verse, and thou / Beside me, singing in the wilderness...” (quatrain 11). The difference with earlier versions of the Rubái'yát is immediately obvious: this time the manuscript was not on paper but on vellum, and it was entirely gilt with gold leaf, including the gold-stamped cover -cf. fig. 2). This again was a collaboration, in more senses than one: the figures depicted in the decorated borders were designed by Morris and Burne-Jones, and painted by Charles Fairfax Murray; and, not being the type of man to do things by half, Morris had the vellum brought to him especially from Rome through Murray himself, who had married an Italian girl

\footnotetext{
${ }^{9}$ https://commons.wikimedia.org/wiki/File:Rubaiyat_Morris Bume-Jones_Manuscript.jpg
} 
and settled in Florence, from there worked as a purveyor of artworks and other necessities for the artists of the Pre-Raphaelite community.

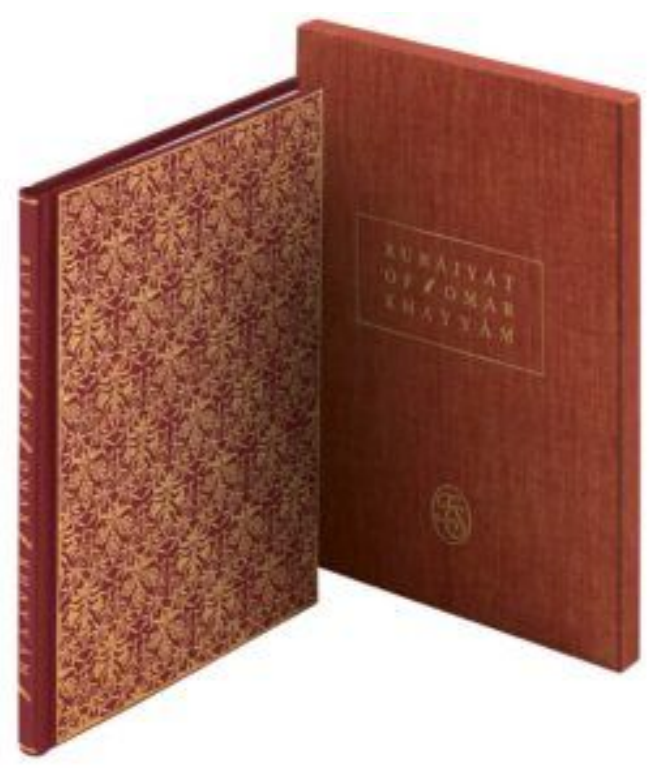

Fig. 2: Rubaiyat of Omar Khayyam, watercolor, bodycolor and gold leaf (1872). Facsimile published by the Folio Society ${ }^{10}$

The book was a labour of love, presented as small jewel, as can be seen from the thinness of the book-less than 25-page long-and its small dimensions, around $15 \mathrm{cms}$ high. The most lavish decoration is kept for the first page (fig. 3), the beginning of the "Kuza Nama" (fig. 4), and the last page (fig. 5). "Kuza Nama" translates as the "books of pots", or "parable of the pots", which draws its name from a recurring metaphor in Khayyám's text: that of God as a potter fashioning the clay out of which men are shaped.

\footnotetext{
10 https:/blogs.foliosociety.com/press-release/press-release-the-rubaiyat-of-omar-khayyam/ (accessed 12/04/2020).
} 


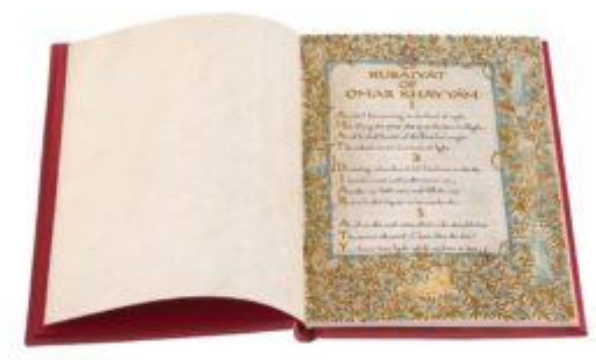

Fig. 3: Rubaiyat (1872), title page. Facsimile Folio Society ${ }^{11}$

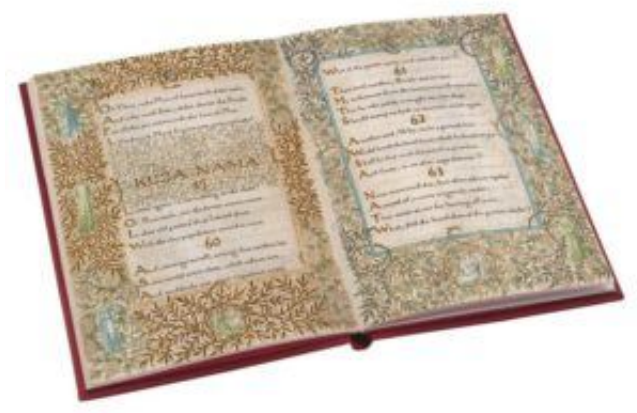

Fig. 4: Rubaiyat (1872), “Kuza Nama”. Facsimile Folio Society ${ }^{12}$

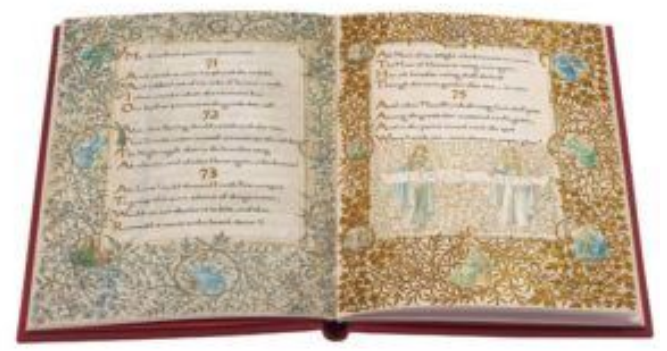

Fig. 5: Rubaiyat (1872), Last page. Facsimile Folio Society ${ }^{13}$

\footnotetext{
${ }^{11}$ https:/blogs.foliosociety.com/press-release/press-release-the-rubaiyat-of-omar-khayyam/

12 https:/blogs.foliosociety.com/press-release/press-release-the-rubaiyat-of-omar-khayyam/
} 
The other pages are more sober, and take up the Blakian layout of interstanzaic foliage, although the treatment is definitely Morris's own. Indeed, the thin gold or green leaves spreading in the margins and through the written lines are clear forebears of one of Morris's favourite themes, the "Willow" pattern. May Morris describes the genesis of the motif when her father, on a walk with her, started taking notes of the variety of shapes in the leaves of the willow trees growing by the side of the Thames close to their house. Morris's "Willow Bough" wallpaper was one of his most successful creations as a designer; but it is worth nothing that the motif had first appeared on the cover of his 1870 Book of Verse, and in the margins of his Rubái'yát fifteen years before his wall-paper was commercialized. It is also present in his textiles, like the "Tulip and Willow" fabric and here too, the design, dated 1873, seems to derive immediately from the decorative drawings in these early manuscripts. In the same way, the longer leaves in front of quatrain 40 or 43, for example, also recall his numerous variations on the spectacularly curved acanthus or vine leaves used in his textile or printed creations, after 1873. This confirms the intimate relationship between text and textile, all dealt with in a very similar way in Morris's designs. It is clear that as a creator, Morris hardly made any difference between text and textile.

Although our gaze is instantly caught by the gilt and painted illuminations, Morris's "main preoccupation was with the writing” (Nash 299). Remembering that the whole page was no more than $16 \mathrm{~cm}$ long, we realize how small were the letters he formed. Paul Nash explains that this version is in "tiny, formal, almost monocline roman minuscule, with straight $y$, cut-off $f$, g with rounded flourish and sticking up ear, and tall ascenders with minute tick serifs". Nash goes on to add that Morris saw calligraphy as leisure, working "only on Sundays and at odds moments snatched from an overpoweringly busy life" (Nash 299); and, "as with other aspects of Morris's work, it is most engaging to imagine this burly, vastly impatient man, subject to famous rages, subjecting himself to the most minute and exacting tasks, such as writing microscopically with a crow quill” (Nash 298). The comparison with a more quickly scrolled notation at the end of the book clearly demonstrates the much higher degree of application on the quatrains themselves. Graily Hewitt, who was commissioned to work on some of Morris's books in the mid-1890s, insisted on the fact that his letters were "all based on humanistic precedent" (Hewitt 4), meaning that Morris placed himself directly within the line of the mediaeval and renaissance manuscript scribes he had studied in depth. Hewitt explained that in technical terms Morris's writing was "extraordinarily strong, though rough, and disturbed, for [him-Graily Hewitt], with the dash of diagonal strokes he made for his

\footnotetext{
${ }^{13}$ https:/blogs.foliosociety.com/press-release/press-release-the-rubaiyat-of-omar-khayyam/
} 
commas and tails to p's and q's; and the pages were somewhat uneven with each other (because he did not cut his pens" (Hewitt 6). These hands were written with a crow quill (a precision he got from May Morris herself, Hewitt 7), in flat pen work-i.e. without recourse to thick-and-thins alternations-which adds to the legibility of the page, always a great concern for Morris (see Gadoin 2017). This preoccupation also accounts for his "widely spaced lines", and his "delight in long ascenders and comparatively short descenders" (Hewitt 7). But the quatrains retain a hand-drawn, and sometimes slightly irregular quality, widely different from mechanical work. The pages, though delightful, are not without their faults, with stray lines sometimes isolated from the rest of the quatrain at the bottom or the top of a page, and occasionally ill-formed letters, but they show Morris honing his skills and practicing on the shape of letters long before he designed his own set of fonts for the Kelmscott Press-his own calligraphic efforts being quite close to his "Golden type". This shows the profoundly coherent quality of the whole of Morris's activities as a designer, who "saw" texts for their content and their visual appearance. While the marginal decoration in his manuscripts shared the same naturalistic motifs as his textile designs, his calligraphic exercises directly paved the way for his work on typographic letters, as a printer and a publisher of luxury books. The whole of these "exercises" show him slowly devising a unified visual idiom, running through his fabrics, wallpapers, books and novels.

Stepping back a little from the contemplation of these works, it is easy to imagine what theoreticians of post-colonial studies might object to Morris's deeply transmedial and transcultural creations. Just as Edward FitzGerald's translation of the Rubái'yát had appropriated the Persian quatrains to convey a typically Western carpe diem type of message, Morris produced a book which bears the stamp of all his idiosyncrasies, and erases any sign of Khayyám's native culture. These were already few and far between in FitzGerald's rendering of the poems: although he did preserve a few proper names like Jamshid, Kaikobad, Kaikhosru, Mahmud or Bahram for the sake of local colour, these are made to coexist with Christian concepts like those of Heaven, Destiny, Angels, Jesus and the "white hand of Moses" (quatrain 4). FitzGerald even lifts entire metaphors from the book of Ecclesiastes (3:20), in what sounds like poetic paraphrase of the biblical text: "we too into the dust descend / Dust unto dust, and under dust to lie" (quatrain 23). In that context, the mention of "sultans", a few "caravanserai" and the "Ramazan" is hardly enough to really "persianise" the text. The same refusal to exoticise his material can be seen in Morris's work, which hardly tries to interact with the text: the presence of lemons might be understood as illustrating the "bitter fruit" mentioned in quatrain 39, just as grapes seem to visually materialise the many allusions to wine, the vine, and taverns. But that is not enough to turn the marginal decoration into an illustration of the text, far from it. The only concession to 
Persian culture comes with the use of the words "Tamam shud" on the last page, meaning "the end" in Farsi. But the phylactery showing the words is held by two of Burne-Jones's typically Pre-Raphaelite creatures: tall thin blonde neoBotticellian beauties who have little to do in the collective imaginary with Oriental women. Nor do his musician angels play on oriental instruments; the obvious relationship here is rather with the marginal vignettes of some mediaeval Bibles.

This is all the more surprising as Morris was in fact very knowledgeable on Persian culture: he owned magnificent Persian carpets, ${ }^{14}$ which served as sources of inspiration for his own carpet designing work, as attested by his choice of names like "Ispahan". He collected examples of the Islamic arts, like metal pots and trays, as well as ceramic plates, and also used as models the objects and fabrics in the collections of the South Kensington Museum (now the V\&A). Above all, he acquired a magnificent illustrated manuscript of the ancient Persian epic the Sháh Námeh, copied in 1621 in Asterabad (Northen Iran), now at the Fitzwilliam Museum in Cambridge; and at some point in the early 1880s he also undertook a translation of the Sháh Námeh from the preexisting French translation of Jules Mohl, though he left it unfinished. However, it is very probable that most of these acquisitions came in the 1880s, and thus followed rather than preceded the 1872 work on the Rubái'yát. So we probably have to understand the logic of his involvement with Persia the other way round: it may well be that the manuscript of the Rubái'yát was his first foray into Persian culture, and that it actually started what was to be a deep interest in Oriental culture.

In illuminated manuscripts, text and illustration, the verbal and the visual concur together to build the global sense of the work, a sense derived from the association of linguistic and graphic signifiers; and whatever the language used, the illustrations give the book a universal quality, immediately graspable through the senses. There is much evidence that Morris's love of literature was filtered through his mostly sensuous gifts of perception as a designer. In that sense, his work on manuscripts was not mere superficial decoration, but a way of providing sensuous access to the work. Hence, probably, his extremely comfortable type of relationship with translation, from languages as exotic as Latin, Greek, Persian or Icelandic; for translation, just like visual decoration, was to him a way of making a text accessible, appropriating it in order to bring it closer to its reading public.

\footnotetext{
14 See http://collections.vam.ac.uk/item/O98834/carpet-unknown/ (accessed 12/04/2020).
} 


\section{References}

Braesel, Michaela. "William Morris, Edward Burne-Jones and The Rubáiyát of Omar Khayam”. Apollo, 159 (2004), 47-56. Print.

Djavadi, Hasan. Persian Literary Influence on English Literature. Mazda Publishers, University of Michigan, 2005. Print.

Dreyfus John. “The Kelmscott Press”. William Morris. Ed. Linda Parry. London: Philip Wilson Publishers in association with the V\&A Museum, 1996, 310-341. Print.

Dunlap, Joseph. The Road to Kelmscott. William Morris and the Book Arts before the Founding of the Kelmscott Press (unpublished doctoral thesis). Columbia University, 1972. Print.

---. "Morris and the Book Arts before the Kelmscott Press”. Victorian Poetry 13 (1975), 141-57, 147, 153. Print.

Faulkner, Peter. “The Writer”. William Morris. Ed. Linda Parry. London: Philip Wilson \& V\&A Museum, 1996, 44-71. Print.

Gadoin, Isabelle. "Lorsque la traduction se fait transubstantiation: Omar Khayyám, version Edward Fitzgerald”. Le monde anglophone et le Moyen-Orient. Paris : Editions du Temps, 2000, 121-137. Print.

---. "De la calligraphie à la typographie : le livre idéal selon William Morris”. Motifs, la revue en ligne de HCTI-EA4249, 2017, http://revuemotifs.fr/?page id=781 (accessed 26/05/2019).

Gaines, Barry. “The Editions of Malory in the Early Nineteenth Century”. Papers of the Bibliographical Society of America 68.1 (First Quarter, 1974), 16. Print.

Goldfarb, Sheldon. "Edward FitzGerald [formerly Purcell] (1809-1883)”. Dictionary of National Biography, https://doi-org.ezproxy.univparis3.fr/10.1093/ref:odnb/9548 (accessed 18/05/2019).

Heron-Allen, Edward. The Rubai'yat of Omar Khayyam; being a facsimile of the manuscript in the Bodleian Library at Oxford, with a transcription into Modern Persian characters. Translated, with an introduction, and notes, and a bibliography, and some sidelights upon Edward FitzGerald's poem. H.S. Nichols ltd, 1898. Print.

Hewitt, Graily. “The Illuminated Manuscripts of William Morris”. Papers read before the Double Crown Club in 1934 for the Centenary year of his birth. Print.

Kelvin, Norman, ed. The Collected Letters of William Morris. Princeton, New Jersey: Princeton UP, 1991. Print.

Martin, William H. and Sandra Mason. “The Illustration of FitzGerald’s Rubáiyát and its contribution to enduring popularity. FitzGerald's Rubáiyát of Omar Khayyám: Popularity and Neglect. Eds. Adrian Poole et al. London: Anthem Press, 2011, chapter 14, 233-248. Print.

McCarthy, Fiona. William Morris: a Life for our Times. London: Faber \& Faber, 1994. Print.

---. The Last Pre-Raphaelite: Edward Burne-Jones and the Victorian Imagination. London: Faber and Faber, 2011. Print.

Morris, William and Edward Burne-Jones. Rubaiyat of Omar Khayyam. British Library; Add. 37832. 
Nash John. “Calligraphy”. William Morris. Ed. Linda Parry. London: P. Wilson \& V\&A Museum, 1996, 296-309. Print.

Needham, Paul, Dunlap, Joseph and John Dreyfus. William Morris and the Art of the Book. New York; 1976. Print.

Parry, Linda. William Morris: Textiles. London: Weidenfeld and Nicholson, 1983. Print.

---, ed. William Morris (Exhibition Catalogue). London: Philip Wilson Publishers in association with the V\&A Museum, 1996. Print.

Peterson, Bill and Sylvia Holton Peterson. The Library of William Morris. A Catalogue (website), https://williammorrislibrary.wordpress.com/ (accessed 26/05/2019).

Thomas, F.W. “Cowell, Edward Byles (1826-1903)” (revised by J.B. Katz). Dictionary of National Biography, https://doi-org.ezproxy.univparis3.fr/10.1093/ref:odnb/3255, (accessed 18/05/2019).

Wilmer, Clive. “A Victorian Poem: Edward FitzGerald’s Rubáiyát of Omar Khayyám”, in Adrian Poole et al. (eds.), FitzGerald's Rubáiyát of Omar Khayyám: Popularity and Neglect. London: Anthem Press, 2011, 45-54. Print.

\section{BIONOTE}

Isabelle Gadoin is Professor of British Art and Literature at the University of Poitiers, France. She is a Thomas Hardy specialist, and one of the founding members of "FATHOM" ("French Association for Thomas Hardy Studies") as well as the co-editor of the online journal of the association. Apart from her interest in Victorian literature, she has worked mostly on the question of visual perception and the apprehension of space in novels and travel narratives, and more generally on Visual Culture Studies and text-and-image studies, on which she has published extensively. She has taught in the Master Degree on Text and Image at the University of Poitiers, and is the president of "SAIT" ("Société Angliciste Image-Texte”, the French Society for Intermedial and Intertextual Studies). She also holds an MA in Art History from the Sorbonne, for which she specialized in Islamic art, researching the reception of Islamic art in Victorian Britain, with a short unpublished thesis on George Salting and his collections of Persian art. She has published several articles and co-edited two volumes on the subject: Rêver d'Orient, Connaître l'Orient (Lyon, Presses de l'ENS, 2009) and Figures pionnières de l'Orientalisme: Convergences européennes (Revue Res Orientales $\left.n^{\circ} 20,2012\right)$.

Email: isabelle.gadoin@univ-poitiers.fr 